Original Research Paper

\title{
Analysis of The Heat Island Phenomenon in Makassar, South Sulawesi, Indonesia
}

\author{
${ }^{1}$ Rosmini Maru, ${ }^{2}$ Ichsan Invanni Baharuddin, ${ }^{3}$ Ramli Umar, \\ ${ }^{4}$ Rusman Rasyid, ${ }^{5}$ Uca, ${ }^{6}$ Wahidah Sanusi and ${ }^{7}$ Bayudin \\ 1,2,3,4,5, Department of Geography, Faculty of Mathematics and Natural Sciences, State University of Makassar, Indonesia \\ ${ }^{4}$ Geography Education Program, University of Khairun, Indonesia \\ ${ }^{6}$ Department of Mathematic, Faculty of Mathematics and Natural Sciences, State University of Makassar, Indonesia
}

Article history

Received: 2014-08-15

Revised: 2014-09-05

Accepted: 2015-01-09

Corresponding Author:

Rosmini Maru

Department of Geography,

Faculty of Mathematics and

Natural Sciences, State

University of Makassar,

Indonesia

Email: rosminimaru@unm.ac.id

\begin{abstract}
Urban Heat Island phenomenon (UHI) is one of the city microclimate phenomenon that mostly hit many big cities in the World, including Makassar, Indonesia. Therefore, this study aimed to analyze the phenomenon of UHI and UHII in Makassar and the surrounding areas. The method used in this study is the analysis of primary data through measurements taken directly to the varied station locations. The measurements are determined by purposive sampling toward the variety of different land uses. The measurements were taken at 11:00 am until 1:00 pm Central Indonesian Time (WITA) and at night from 09.00 to $11.00 \mathrm{pm}$. The results showed that the mean temperature was $31.29^{\circ} \mathrm{C}$ during the day and $27.4^{\circ} \mathrm{C}$ at night. Spatially, the day time showed that the high temperatures $\left(32\right.$ to $\left.35^{\circ} \mathrm{C}\right)$ are generally located in the downtown areas which are crowded with buildings such as residential, offices and shops. Meanwhile, a lower temperature $\left(29\right.$ to $\left.31^{\circ} \mathrm{C}\right)$ is generally located in countrysides or outside the city in the form of green areas and open land. The results show that a fairly high temperature causes the comfort of the city the temperatures reduced. Therefore, handle UHI phenomenon needs to be done in an integrated and sustainable.
\end{abstract}

Keywords: Urban Heat Island (UHI), The Urban Heat Island Intensity (UHII), Makassar, Micro Climate

\section{Introduction}

Based on the monitoring results of the Meteorology and Geophysics Agency (BMG), it is known that at the present time, there has been a shift in weather patterns. For example, it has experienced a rainy season during the year which are recognized as La-Nina storms in 2010. In contrast, the prolonged dry season with a high enough temperature caused by the low air temperature in the Pacific Ocean and the lower part of atmospheric temperatures known as El-Nino storms (Sellers and Robinson, 1986). Both are frequent disasters struck Indonesia, especially El-Nino. The phenomenon has several times happened in Indonesia in general and South Sulawesi in particular. Extreme events is different than usual as the influence of meteorological conditions that are not balanced. According to the Purnomohadi (1995) the state meteorological unbalanced can be caused by increased greenhouse gases. The increase in these gases especially $\mathrm{CO}_{2}$ in the atmosphere and the Earth's surface has led to the change of weather patterns and rising temperatures or global warming. Furthermore, the situation can give effect to an increase in temperature of the Earth's surface. The phenomenon of significant temperature increases mainly occurred in major cities in the World. An increase in temperature the city phenomenon commonly referred to as the Urban Heat Island (UHI). Said to be the UHI because when viewed from above then the phenomenon is shaped like the island with the core at the center of the city (Fig. 1).

This phenomenon is not only influenced by greenhouse gases or global warming, however this phenomenon more caused by various properties and the surface shape of the city as an area dominated by buildings made of concrete. The situation is aggravated with increased anthropogenic activity that happened in the city area (Ahmad and Hashim, 2010; Purnomohadi, 1995). This is in line with Auliciems (1997) that global warming also together with anthropogenic heat increases the temperature of the city. The process of urbanization as a result impact of anthropogenic activities to reduced use of natural land into developed regions (Oke 1987; Tso 1994; Vaughan and dan Cracnell, 1992). 


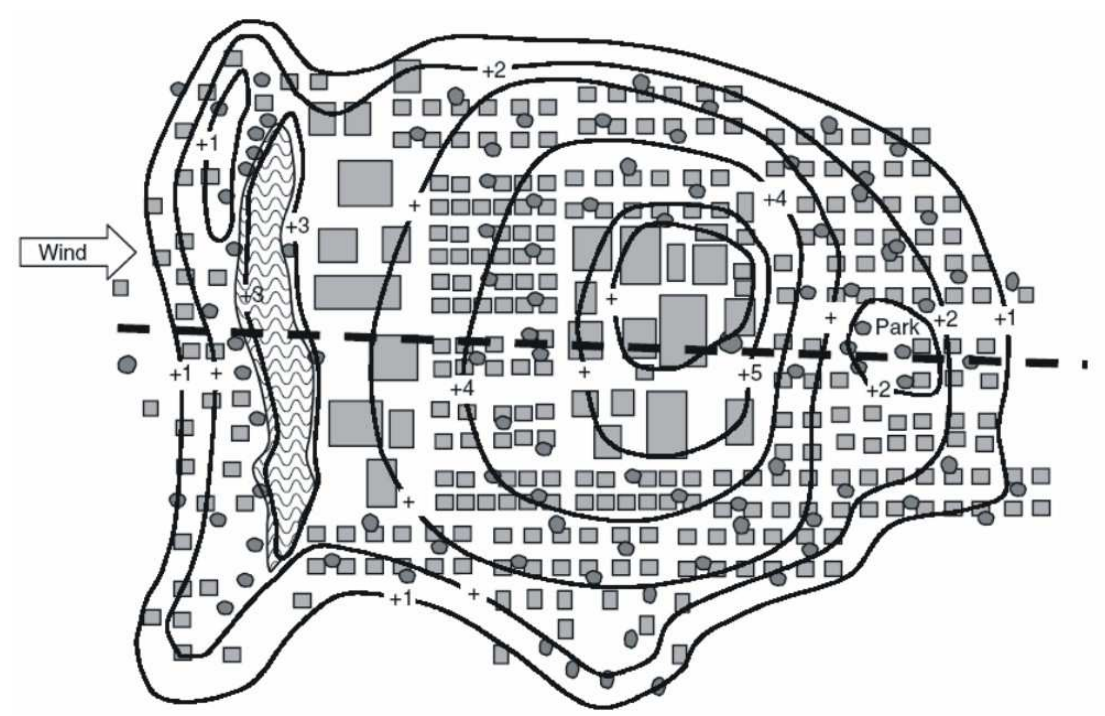

Fig. 1. The phenomenon of spatial UHI in the form of the highest isotherm the center of the image as a heat island (Voogt, 2002)

This according to the results of the study Kusaka and Kimura (2004) in Tokyo, Memon et al. (2010) in Hong Kong and Jusuf et al. (2007) in Singapore showed that the influence of anthropogenic factors and cover the surface of the soil is very large while the impact rather than just reaching $0.15^{\circ} \mathrm{C}$ albedo.

The amount of anthropogenic influences seemed to give the impression to the less important of the other factors. Therefore, several studies suggest that greenhouse gases which have been referred to as the main cause of global warming, it does not provide influence which is significant to the occurrence of UHI phenomenon, experienced by various cities in this world. Statistical analysis by Ozdemir et al. (2012) in the Anatolian Peninsula, Europe explained that, there was no significant increase in the daily minimum temperature in the period 1965 to 2006 in the rural areas. Whenever, in the city has increased significantly to reach an increase of $5^{\circ} \mathrm{C}$. The phenomenon of rising temperatures in urban areas as tangible evidence of the occurrence of the phenomenon of UHI in the region. This study concluded that global warming in this case the emissions of $\mathrm{CO}_{2}$ in the atmosphere rather than as the main causes of the phenomenon of UHI.

Various studies related to the results of the study, including by Borthakur and Nath (2012) at Metropolitan Guwahati, Lo and Quattrochi (2003) in Georgia, Golden (2004) in Phoenix, Arizona and Effendy et al. (2006) in Greater Jakarta Indonesia. Results of their study confirms that the occurrence of UHI phenomenon is caused by changes in land use which is significant in the city area. Changes in land use causing an increase in surface temperature in urban areas. Therefore, the urban area of the temperature becomes higher than the surrounding area commonly referred to as the phenomenon of the Urban Heat Island (UHI). That has been true in many areas in the city such as Kuala Lumpur in 1988, namely a simple pattern of high temperature (29$32^{\circ} \mathrm{C}$ ) scattered about across the study area. Meanwhile, high temperatures exceeding $32^{\circ} \mathrm{C}$ prevailing around town Kepong-Jinjang (Ahmad and Hashim 2010).

The development of UHI phenomenon in many major cities in the World interest in climate experts to study in depth and perform the quantification of the phenomenon. Therefore, various methods are used, including direct measurement and secondary data analysis done by Maru and Ahmad (2014a; 2014b) in Jakarta, Kershaw et al. (2010) in the UK. Another method is where the satellite imagery as performed by Liu and Zhang (2011). Although methods is vary, but all show that has a high temperature prevailing in the downtown area while lower temperatures occurred outside the city.

UHI phenomenon more widespread causing loss can even cause death. As a study conducted by Johnson and Wilson (2009) in Philadelphia, USA showed that the concentration of the population died in the area of high UHI. He also explained that other variables also showed that there is influence between poverty with UHI phenomenon prevailing in the study area. Although, it has been known that greenhouse gases are not significant influence to the increase of UHI but if it is valid continuously it will provide a greater negative impact. In accordance with the views Intergovermental Panel on Climate Change (IPCC) (IPCC, 2014) that the increase in greenhouse gases will continue to rise causing an increase in temperature continuously and persist for a long time.

In addition, the phenomenon of UHI requires serious attention because it affects the various aspects of community life such as changes in cropping patterns, lower levels of comfort, the emergence of various kinds of diseases, the explosion of various pests include locusts wanderer on the island of Sumba, East Nusa 
Tenggara and Lampung (Ahmad et al., 2014), the explosion of caterpillar population in some areas of Indonesia (Wadrianto, 2015), a giant jelly fish attacks in Japan at the present time. Therefore, this research is important to provide early information on the existence and development of the UHI in Makassar, so the handler can be done quickly and accurately.

According to Purnomohadi (1995), unbalanced meteorological conditions can be caused by increasing greenhouse gases. The increase in these gases, especially $\mathrm{CO}_{2}$ in the atmosphere and the Earth's surface causes the increase in temperature and the changes in weather patterns. The high temperature with an increasingly widespread HI phenomenon causes damages. One element of a highly influential climate change is an increase in temperature. According to Intergovernmental Panel on Climate Change (IPCC) (IPCC, 2014) that the increase in greenhouse gases will continue to rise causing an increase in temperature continuously and persist for a long time.

The increase in temperature and UHI phenomenon occurs in various regions in Indonesia and even in various regions on the Earth's surface, but because the vast territory this study will only focus on one area that is thought to have the potential rate of increase in temperature and a very fast UHI phenomenon that is in the Makassar. Moreover, according to Ahmad et al. (2014), Makassar is included in the classification of high drought index $(>33.3 \%)$.

The problem is approached geographically by using an ecological approach and spatial approach. Ecological approach is intended to analyze the increase of the heat island phenomenon with a variety of causes and impacts. While the spatial approach is intended to analyze the areas that experienced the phenomenon of UHI and the intensity of the various land use patterns.

\section{Materials and Methods}

This study focused on the Makassar which is located in the south arm of South Sulawesi, namely on the west coast. Therefore, this region is dominated by a rather gentle topography with a height of between 0 to 20 meters above sea level (msl). Makassar City is the largest and most populous city in eastern Indonesia. Moreover, according to Ahmad at al. (2014), that the City of Makassar belongs to the class of the drought index is high. Therefore, this area has the potential rate of increase in temperature and a very fast UHI phenomenon in Indonesian eastern portion. Studies in this area will be approached to analyze the spatial and ecological areas that experienced the phenomenon of UHI and intensity of the various land use patterns.

The tools used in this study, are as follows: A set of computers or laptops that are used to analyze the data both secondary data and primary data, so that the obtained results of the study. Geographic Position System (GPS) MAP62st large type that is used to determine the location or position than the measurement locations making it easy to put in the picture. Subsequently, the temperature was measured at each location by using the mercury thermometer of four pieces. Although the tool is simple but it can be used to measure the temperature with good results in the area of study. Olympus E-500 Kit type digital cameras are used to record the situation rather than the location of measurement. In addition, no less important is the motorcycle as much as four. This type of vehicle is used to facilitate the study reach all locations in a short time, so that measurements can be made at all locations with a predetermined time. Meanwhile, the materials used in this study are: Administrative maps of Makassar and the surrounding areas, landsat imagery, land use maps of Makassar and observation sheet. This is done to analyze the relationship between the type of land use with the UHI phenomenon that occurs Makassar City area.

This study involved the collection of primary data and secondary data. Primary data collection was the direct measurement to the air temperature in the study area (Fig. 2) using a mercury thermometer. Based rather than one of the objectives of this study is to see the tops of the heat island in Makassar, the time measurements carried out in June 2014. This is done because of Makassar is one of the town, which is located in eastern Indonesia which has two seasons: The rainy season and dry season in accordance with the rainfall in the region (Fadholi, 2012). The rainy season lasts between August and March, while the dry season lasts from April to July. Keep in mind that the surface temperature also depends on the second season, which in the dry season usually hot reception on the Earth's surface is much higher than during the rainy season. Therefore, the peaks of heat is expected to occur between April and July is the June. In addition, measurements carried out on weekdays because several studies including by Ohashi et al. (2006) states that the waste heat from the air conditioning has led to the increase in temperature of $1-2^{\circ} \mathrm{C}$ or more on weekdays in the office area of Tokyo. Therefore, to maximize the findings of the tops of the heat the measurements are made on weekdays.

This study begins with a review of the literature that is read and studied a variety of related sources such as relevant books, articles and reports the results of research both within and outside the country like in Kuala Lumpur, Tokyo, Singapore and the others. Furthermore, the administrative map making and land use are made based on Landsat imagery and data administration of Makassar. This is done to make it easier to determine the locations of measurement. Based on study results Ahmad at al. (2011) who showed that land use can affect the surface temperature distribution, the measurement locations are set according to different land use that is farmland, ricefield, embankment, settlements, water bodies, shrubs and savannas. 


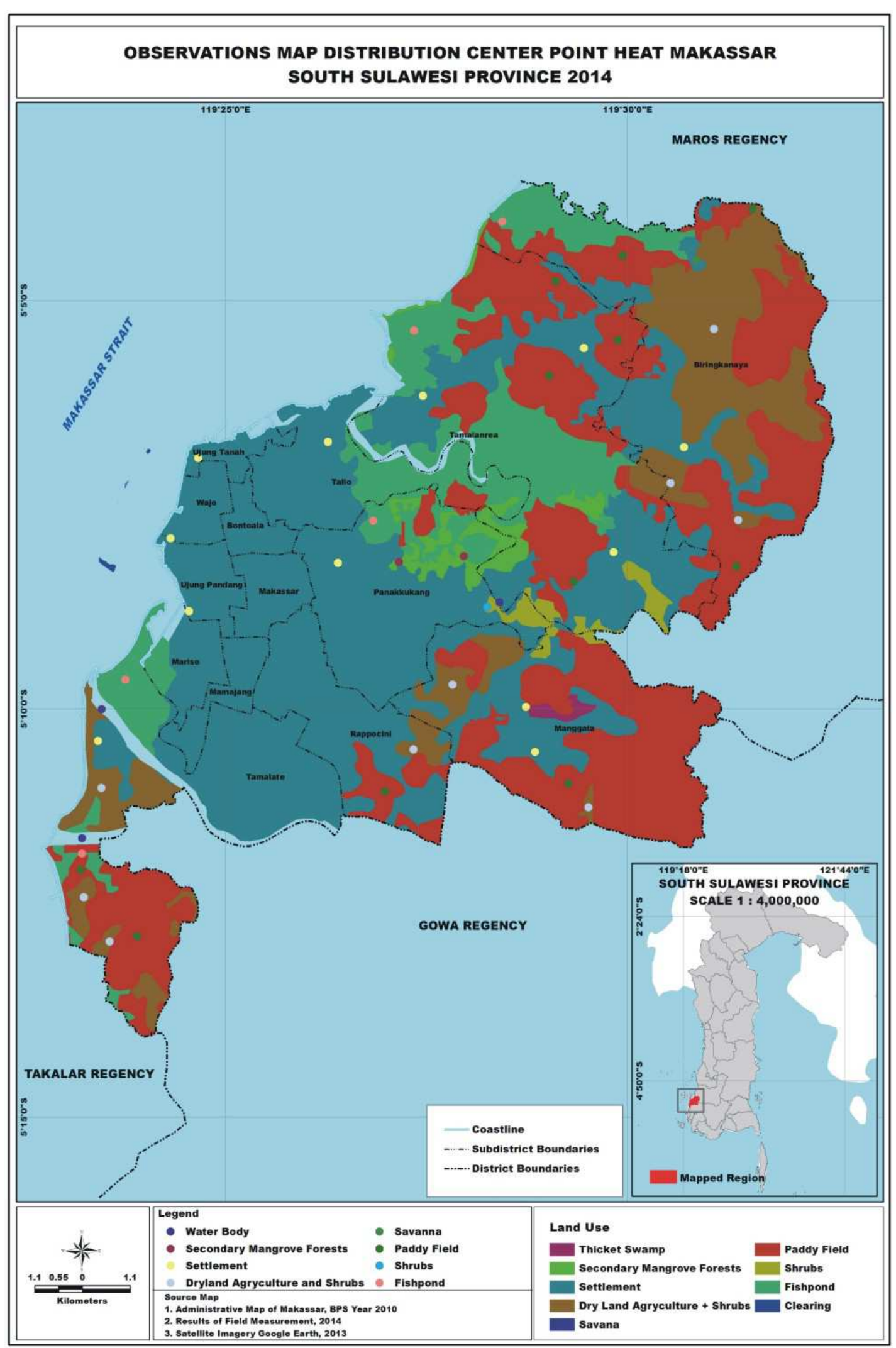

Fig. 2. Map location of measurement 
Determining the location of the measurement is made in proportion purposive sampling, where the number of measurement points is determined based on the breadth of each land use in accordance with the needs and affordability. The measurement locations are shown in Fig. 2.

In addition to measurements, also conducted interviews with the people of Makassar by using the interview guide. This is done to determine how much public knowledge about the occurrence of an increase in temperature in the city of Makassar. In addition, also known how perceptions and patterns of their lives to comfort temperature in the city of Makassar in everyday life.

Various secondary data employed in this research were gained from many instances under the authority of the Province of South Sulawesi and its surroundings, such as administration map in Development Planning Agency at Sub-National Level (BAPPEDA), citra landsat in National Institute of Aeronautics and Space (LAPAN), Earth surface's map in National Land Survey Coordinating Board (BAKOSURTANAL), the land use map in land affairs instance. Those data were used for the need of analysis in order to make accurate conclusion. The data obtained is used as an input for temperature mapping. Furthermore, these data are used to analyze the phenomenon of UHI in Makassar using 'kriging interpolation method' is one method of interpolation that connects the points that have the same temperature on the surface of the Earth. The final result obtained is an isotherm map of Makassar in the afternoon and the evening.

\section{Results}

\section{The Isotherm of Makassar}

Isotherm is the line that connects the points on the surface of the Earth that have the same temperature (Fig. 3 and 4). Figure 3 illustrates the temperature distribution map of Makassar in the day. Temperatures during the day range from 29 to $35^{\circ} \mathrm{C}$. It also spatially showed that high temperatures (32 to $35^{\circ} \mathrm{C}$ ) are generally located in the downtown area which are densely filled by buildings such as residences, offices and shops. Meanwhile, lower temperatures $\left(29\right.$ to $\left.31^{\circ} \mathrm{C}\right)$ in general are in the edge region and outside the city in the form of green areas and open land.

Furthermore, the temperature at night time is shown by Fig. 4. The temperature of night time is lower than that of the day. The temperature at night time only range between 24 to $28^{\circ} \mathrm{C}$. Temperature distribution pattern shows a similar trend during the day in which high temperatures are generally felt in the city center, while low temperature is from the edge to the outside of Makassar. At night time, temperature of the coastal area is higher than that of the other regions. This phenomenon is caused by onshore winds during the night and the sea breeze during the day. Therefore, the temperature of the beach at night was still warm, otherwise the day was cool. Based on both isotherm either by day or night, it is known also UHII Makassar City is $6.0^{\circ} \mathrm{C}$ during the day and $0.8^{\circ} \mathrm{C}$ at night.

\section{Temperature and Land Use}

Urbanization problem is a problem for several major cities in Indonesia, including Makassar. The reputation of Makassar as the administrative capital, the city of commerce and the city of education has attracted the people from outside the city to come into Makassar City. This migration takes place every year causing considerably high population density. As the consequence there was an increase in the number of basic needs to people such as public facility, housing and the other such items. This causes the increase of developing area of the region. One of the results of the study showed that the highest temperature happened in housing areas and savanna (Table 1 and Fig. 5).

In general, the temperature during the day is higher than the temperature at night in Makassar. This is in accordance with Table 1 and Fig. 5 that the average air temperature during the day was $31.1^{\circ} \mathrm{C}$ with high air temperature is $32.5^{\circ} \mathrm{C}$ in the ponds and $31.5^{\circ} \mathrm{C}$ in the settlement area/office. Conversely, a low temperature was $29.4^{\circ} \mathrm{C}$ which occurs on land use bush/shrub and water bodies that is $29^{\circ} \mathrm{C}$. In contrast, the average temperature in the city of Makassar at night time was $26.7^{\circ} \mathrm{C}$ the highest temperature was $27.1^{\circ} \mathrm{C}$ in the area of water bodies with the lowest temperature was $25.5^{\circ} \mathrm{C}$ in the savanna region.

Table 1 . The day and night temperature based on land use

\begin{tabular}{lll}
\hline The land use & $\begin{array}{l}\text { Daytime } \\
\left({ }^{\circ} \mathrm{C}\right)\end{array}$ & $\begin{array}{l}\text { Night } \\
\text { time }\left({ }^{\circ} \mathrm{C}\right)\end{array}$ \\
\hline Farmland + bushes & 31.4 & 27.0 \\
Ricefield & 31.3 & 27.0 \\
Fishpond & 31.5 & 27.0 \\
Settlement/office & 31.5 & 26.7 \\
Water bodies & 29.8 & 27.1 \\
Underbrush & 29.4 & 26.6 \\
Savanna & 32.5 & 25.5 \\
Average & 31.1 & 26.7 \\
\hline
\end{tabular}

Source: The results of data analysis in 2014 


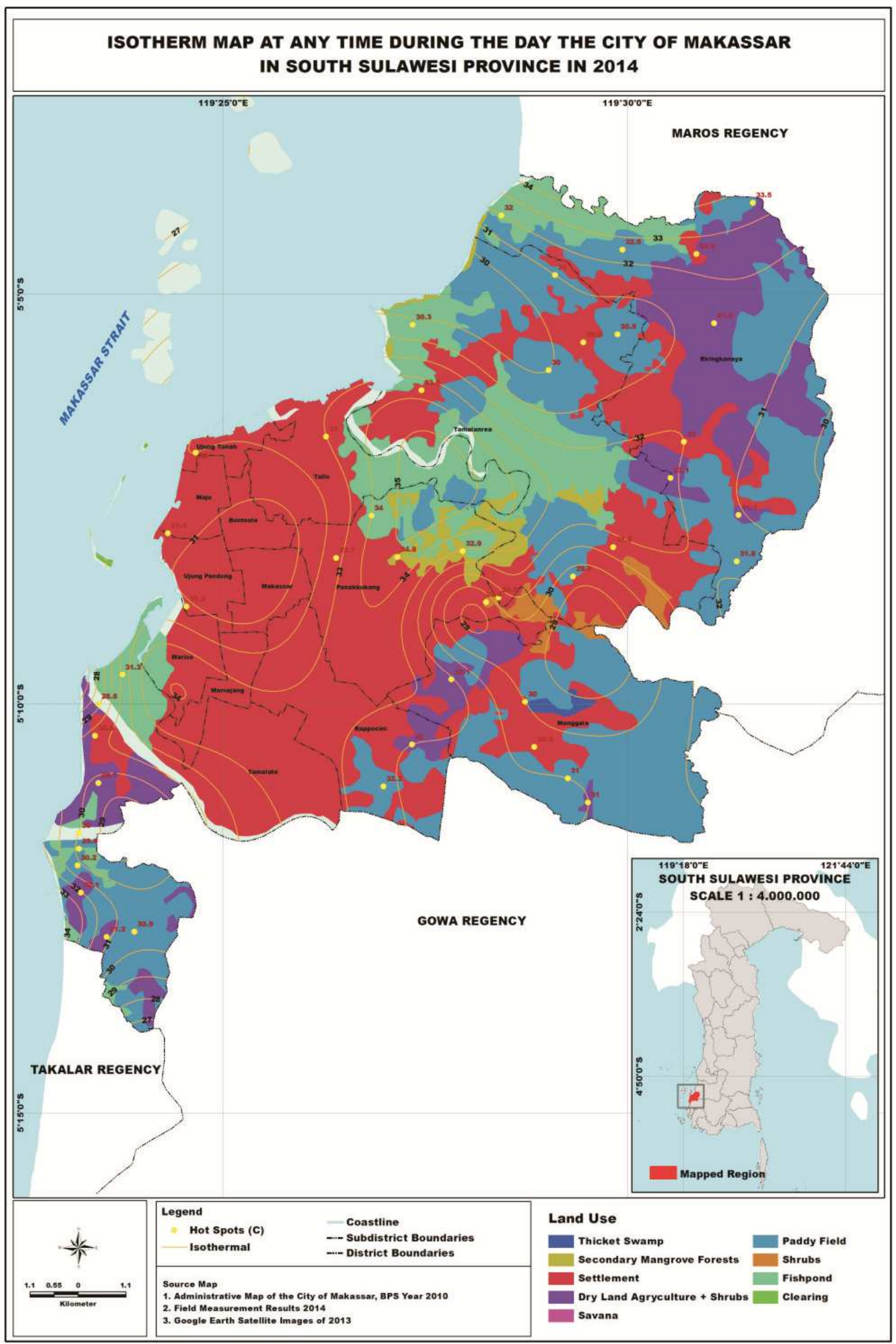

Fig. 3. Isotherm map at day time in Makassar 


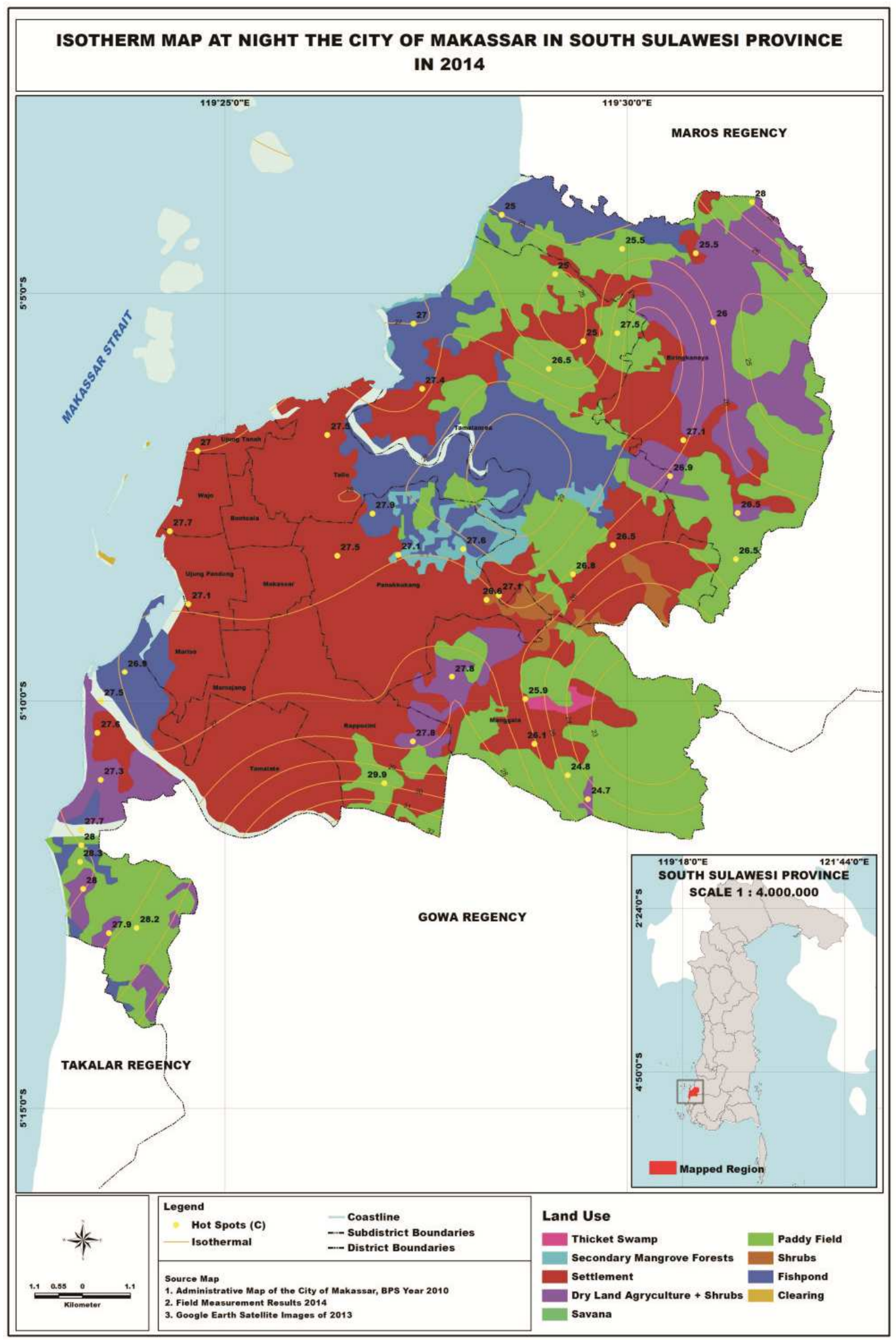

Fig. 4. Isotherm map at night time in Makassar 


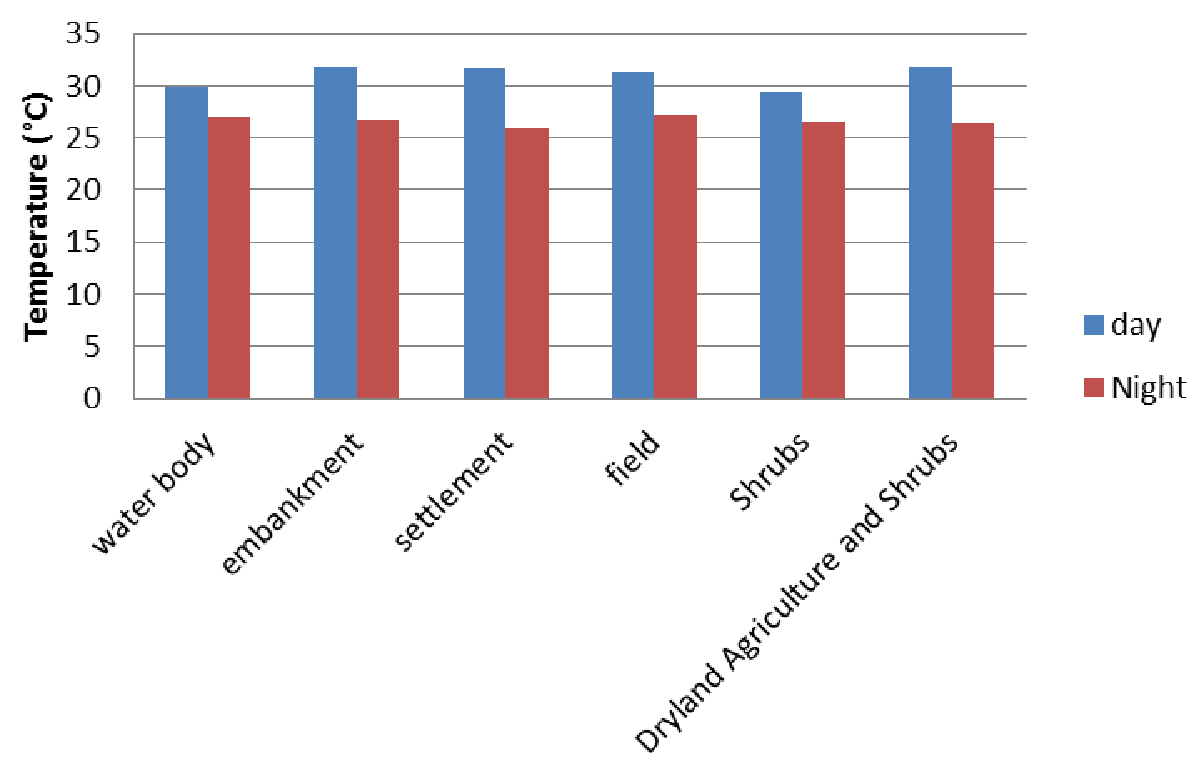

Fig. 5. Comparison of Makassar mean air temperature during the day and night based on different land use

\section{Discussion}

Spatially known that there is a difference in temperature between the central region, the edge and the outside the city of Makassar which is commonly known as the Urban Heat Island Intensity (UHII). Based on this, the results of the study indicate that UHII of Makassar is $6.0^{\circ} \mathrm{C}$ during the day and $0.8^{\circ} \mathrm{C}$ at night. The results of this study are very high when compared with the opinions (Hidayati, 1990; Kartojo, 1992; Santoso, 1998) that in tropical regions such as Indonesia, Malaysia, Singapore, Thailand, Laos and the others. The results of the studies in various cities in these countries demonstrate the value of UHI between 0.02 to $1^{\circ} \mathrm{C}$. The results of this study were higher than the results of the study in the city of Jakarta, namely $2.1^{\circ} \mathrm{C}$ in the north to the south and $1.6^{\circ} \mathrm{C}$ for east west direction (Maru and Ahmad, 2014a; 2014b). It is appropriate as well the results of the study by Jamei and Ossen (2012) in Melaka, Malaysia. Results of studies find that the core area of the city is hotter than the expansion area.

The high level of UHII in Makassar is caused by several factors; among them is the weather. At the time of measuring the temperature, it was raining in outside of the city, but sunny in town. In addition, the density of the buildings in the city caused the sheltering effect. This phenomenon leads to deposits in the heat of the city. This further increased the number of high-rise buildings causing the heat can't escape into the atmosphere. Finally, an increase in heat is called the UHI phenomenon in Makassar.

Based on these results the development of the UHI phenomenon in Makassar is already on par with other major cities in the subtropical region. This, according to
Givoni (1998) that some of the results of the study in the subtropical region, that UHII can reach 3 to $5^{\circ} \mathrm{C}$ during the day and 8 to $10^{\circ} \mathrm{C}$ at night. Similar to the findings Streutker (2003) in Houston, Texas (USA); and Svensson and Eliasson (2002) in the city of Gothenburg; and Zeng et al. (2009) in Nanjing. This study uses satellite data, for the entire period of 13 years (19871999) he received an increase in temperature during the day reaches 0 to $8^{\circ} \mathrm{C}$.

Currently, the construction of roads, offices and housing in the city of Makassar can no longer be avoided. This situation, of course led to the increasing of UHI pheomenon and the UHII values in the region. Therefore, it needs to get serious attention from government, private institutions and society. Governments need to create policies regarding the development of green technologies such as procurement of Green Open Space (GOS), city parks, parking lots using grass and energy-saving movement. Meanwhile, the public can make a roof curtain, green walls, green gardens and multiply water bodies like showers near the house or the offices. This can increase the moisture in the city and can further reduce the rate of heat and UHI phenomenon in Makassar.

UHI phenomenon is one of the microclimate phenomenon in urban area that is happening in several big cities in the World, including in Indonesia, particularly in the city of Makassar. This phenomenon is characterized by higher temperatures in the city if compared to the surrounding area or out of the city. The results of interviews with some respondents also showed that the level of comfort in Makassar have decreased due to the high temperatures. It was proved by the results of measurements done during the day and 
night which shows that the average temperature of Makassar is $31.29^{\circ} \mathrm{C}$ at the day time and $27.04^{\circ} \mathrm{C}$ at night. The study carried out by Maru and Ahmad (2012) showed that the average temperature in Makassar is found lower than in Jakarta, although the UHII of Makassar is higher than that of Jakarta. One result of the study was that the average temperature during the weekdays in Utan Kayu (UK) (settlements) was $32.8^{\circ} \mathrm{C}$ with the maximum and minimum temperature were $34.9^{\circ} \mathrm{C}$ which was recorded at $14: 00 \mathrm{pm}$ and $29.1^{\circ} \mathrm{C}$ which was recorded at $06.00 \mathrm{pm}$., respectively.

Wycherley (1967) stated that the most optimum temperature reception in the tropical area is $20.8-22.8^{\circ} \mathrm{C}$. Based on the criteria the temperature in the city of Makassar was considered very high and led to the decreasing level of comfort in the area. This phenomenon gives effect to the increased use of Air Conditioner (AC), fans and others. Furthermore, it does not directly have an impact on the increased use of electricity for the community. Some respondents who were in the city center were interviewed and they say that the current temperature is so high that they had to use air conditioning and ceiling fans in both the daytime or night time. Lifestyle like exactly will increase the rate UHII phenomenon in urban areas.

This is supported by the results of the study indicate that there is a spatial relationship between land use with the ambient temperature in the city of Makassar. High temperatures in the savannah during the day is the effect of the solar radiation, because the measurement time no shelter. Meanwhile, the area of the settlement is the result of a trap heat in the city that can, $t$ be directly out of buildings or residential buildings or offices even experienced repeated reflection, thus causing an increase in temperature in the region. Instead, the results of the study showed that low temperatures occur in the area of water bodies. This is due to the high evaporation in the region causes the surface to become moist air so as to reduce the phenomenon of islands in the region. Based on this, the few studies have shown that the addition of water bodies is one attempt to address the increasing UHI phenomenon such as the study by Steeneveld et al. (2013) in Rotterdam. The results of the study showed that the water bodies can reduce the UHI phenomenon. In addition, the canopy structure also need to be considered in determining the surface temperature (Tan et al., 2010).

Conversely, at night apply a different matter where the highest temperatures prevailing in the area of water bodies. According to Steeneveld et al. (2013) that the nature of the water is slow to accept and slow release heat seem to apply in this area. At night time the water body while releasing heat into the atmosphere causing surface temperatures are still warm at the time of measurement.
Another phenomenon is the cloud cover. If the surface temperature is seen as one of the effects of the light of the sun, the cloud cover can reduce the heat on the surface of the Earth, because it is less exposed to sunlight. However, based on some of the results of such studies by Hanson et al. (1967) shows that the temperature of the Earth's surface caused by the reflection of heat from the Earth's surface. Meanwhile, cloud cover in the atmosphere blocking the release of heat or pollution to the atmosphere. Therefore, cloud cover can increase the surface temperature. It can be felt at the time before the rain which at that time the sun was not up to the Earth's surface, but still hot. It shows that the heat emitted by the Earth is not completely escape into the atmosphere causing surface temperatures are lower layers of the atmosphere is increased

Today, the results of studies on the phenomenon of rising temperatures, such as the UHI has been much discussed especially in many large cities in the World. But in Indonesia, particularly in Makassar is still very limited. Therefore, this brief study can bring more information to the government and the public to understand about climate change in particular microclimate in the city of Makassar. It is very necessary, because it can be used as an initial or reference information for development planning in the future. As a study conducted by Santeramo et al. (2012) in Syria. The study tries to apply the Delphi method in Farming Systems to prioritize things that are central to risk management in Syria. The study is done to put a proper policy interventions. Finally, the implementation of sustainable development and environmentally friendly.

\section{Conclusion}

Based on the results of the study, then drawn some conclusions as follows, namely: The temperature in the city of Makassar is already relatively high and has exceeded the maximum temperature threshold acceptance. This gives a circumstance reduced impact on the comfort level of the urban community. In addition, the temperature difference daylight to night time in downtown lower than the temperature difference outside the city. This happens because the UHI phenomenon that occurs in the city. Furthermore, an increase in the phenomenon of UHI in Makassar impact to the growing UHII between the center, the edge and outside the city of Makassar.

In addition, the study results also showed that there is a spatial relationship between the use of land with the state of the temperature in the city of Makassar. High temperatures occur in residential areas or town centers, conversely low temperatures occur in the area of the water body. However, urbanization in this region very quickly resulting in a change of land use from the original into smaller plots. Therefore, causing the 
temperature in the region is higher than the surrounding area. Based on the criteria Wycherley show that the temperature in the city of Makassar is considered very high and cause the decreasing level of comfort to the temperature by people in the area.

UHI phenomenon is a phenomenon of climate change happened in many cities in the World, including the city of Makassar. This phenomenon should not be underestimated because it can provide an inconvenience for residents of Makassar and the surrounding areas. Therefore, it is necessary to do some efforts in the form of proper mitigation such as maintaining open green spaces, add water bodies, using green technologies like roof curtains, green walls, gardens and others.

This study may open up horizons for the government and the community to understand the phenomenon of UHI in Makassar. It can be used as an initial or reference information in development planning in the future, so it can be implemented sustainable development and environmentally friendly.

\section{Acknowledgement}

This work was financed by State University of Makassar (UNM) under research grant State University of Makassar No.:873/UN36/PL/2014, charged to the UNM DIPA Number: 023.04.2.415222/2014. Moreover, thanks to the students who have assisted in this research activity.

\section{Funding Information}

Overall, this study has used the funds UNM DIPA Number: 023.04.2.415222/2014, as much as IDR. 90,000,000 (ninety million).

\section{Author's Contributions}

Rosmini Maru: Designed the research plan, organized the study and contributed to the writing of the manuscript.

Ichsan Invanni Baharuddin: Develop the methodology used in this study.

Ramli Umar: Create discussion and correcting reference and article review.

Rusman Rasyid: Collect and process secondary data Uca: Process the data image and article review.

Wahidah Sanusi: Analyze spatial data and develop the methodology used in this study.

Bayudin: Contribute to the process of collection and analysis of primary data.

\section{Ethics}

We will be responsible for any issues arising after publication.

\section{References}

Ahmad, S. and N.M. Hashim, 2010. Perubahan iklim mikro di Malaysia. Fakulti Sains Sosial dan Kemanusiaan, Universiti Kebangsaan Malaysia.

Ahmad, S., N.M. Hashim, Y.M. Jani, K. Aiyub and M.F. Mahamod, 2011. The effects of different land uses on the temperature distribution of a humid tropical urban centre. World Applied Sci. J., 13: 63-68.

Ahmad, S., R. Maru, A.M. Jaya and W. Sanusi, 2014. Analyze the level of aridity in the province of South Sulawesi by using Thornthwaite. Malaysian J. Society Space, 10: 15-28.

Auliciems, A., 1997. Human bioclimat and air temperature in Lisbon. Ph.D Thesis, University of Lisbon, pp: 435.

Borthakur, M. and B.K. Nath, 2012. A study of changing urban landscape and heat island phenomenon in Guwahati Metropolitan Area. Int. J. Sci. Res. Public.

Effendy, S., A. Bey, A.F.M. Zain and I. Santosa, 2006. The role of green open spaces in controlling air temperature and urban heat island territory JABOTABEK. J. Agromet Indonesia, 20: 23-33.

Fadholi, A., 2012. Rain and drought according to the Meteorology. Climatology and Geophysics (BMKG).

Givoni, B., 1998. Climate Considerations in Building and Urban Design. 1st Edn., John Wiley and Sons, New York, ISBN-10: 0471291773, pp: 464.

Golden, J.S., 2004. The built environment induced urban heat island effect in rapidly urbanizing arid regionsa sustainable urban engineering complexity. Environ. Sci., 1: 321-349.

DOI: $10.1080 / 15693430412331291698$

Hanson, K.J., T.H.V. Haar and V.E. Suomi, 1967. Reflection of sunlight to space and absorption by the Earth and atmosphere over the United States during spring 1962. Montly Weather Rev., 95: 354-362. DOI: $\quad 10.1175 / 1520-0493(1967) 095<0354$ : ROSTSA $>2.3 . \mathrm{CO} ; 2$

Hidayati, R., 1990. Assessment of climate behavior Jakarta. Changes and differences in the surrounding area. Bogor Agricultural University Graduate.

IPCC, 2014. Climate Change 2014: Synthesis Report: Longer Report. In: Contribution of Working Groups I, II and III to the Fifth Assessment Report of the Intergovernmental Panel on Climate Change Core Writing Team, R.K. Pachauri and L.A. Meyer (Eds.), IPCC, Geneva, Switzerland.

Jamei, E. and D.R. Ossen, 2012. Intra urban air temperature distributions in istoric urban center. Am. J. Environ. Sci., 8: 503-509. DOI: $10.3844 /$ ajessp.2012.503.509

Johnson, D.P. and J.S. Wilson, 2009. The socio-spatial dynamics of extreme urban heat events: The case of heat-related deaths in Philadelphia. J. Applied Geography, 29: 419-434.

DOI: 10.1016/j.apgeog.2008.11.004 
Jusuf, S.K., N.H. Wong, E. Hagen, R. Anggoro and Y. Hong, 2007. The influence of land use on the urban heat island in Singapore. Habitat Int., 31: 232-242. DOI: $10.1016 /$ j.habitatint.2007.02.006

Kartojo, 1992. Cities as central heat (City as Urban Heat Island). Proceedings of the Seminar on Urban Climate Day, PERHIMPI Jakarta.

Kershaw, T., M. Sanderson, D. Coley and M. Eames, 2010. Estimation of the urban heat island for UK climate change projections. Building Serv. Eng. Res. Technol., 31: 251-263.

DOI: $10.1177 / 0143624410365033$

Kusaka, H. and F. Kimura, 2004. Thermal effect of urban canyon struktur on the nocturnal heat island: Numerical experiment using a mesoscale model coupled with an urban canopy model. J. Am. Meteorolgical Society.

Lo, C.P. and A. Quattrochi, 2003. Land-use and landcover change, urban heat island phenomenon and health implications: A remote sensing approach. Photogrammetric Eng. Remote Sensing, 69: 10531063.

Liu, L. and Y. Zhang, 2011. Urban heat island analysis using the Landsat TM data and ASTER data: A case study in Hong Kong. Remote Sens., 3: 1535-1552. DOI: $10.3390 /$ rs3071535

Maru, R. and S. Ahmad, 2014a. Nocturnal air temperature traverses across the city of Jakarta, Indonesia. Global J. Adv. Pure Applied Sci., 02: 19-23.

Maru, R. and S. Ahmad, 2014b. Daytime temperature trend analysis in the city of Jakarta, Indonesia. World Applied Sci. J., 32: 1808-1813.

DOI: 10.5829/idosi.wasj.2014.32.09.1021

Maru, R. and S. Ahmad, 2012. Development of urban heat island in the City of Jakarta, Indonesia in Mohmadisa Hashim, Mohamad Suhaily Yusri Che Ngah and Nasir Nayan. Department of Geography FSK Publisher, UPSI. Tanjong Malim.

Memon, R.A., D.Y.C. Leung, C.H. Liu and M.K.H. Leung, 2010. Urban heat island and its effect on the cooling and heating demands in urban and suburban areas of Hong Kong. Theor. Applied Climatol., 103: 441-450. DOI: 10.1007/s00704-010-0310-y

Ohashi, Y., Y. Genchi, H. Kondo, Y. Kikegawa and H. Yoshikado et al., 2006. Influence of air-conditioning waste heat on air temperature in Tokyo during summer: Numerical experiments using an urban canopy model coupled with a building energy model. J. Applied Meteorol. Climatol., 46: 66-82. DOI: $10.1175 /$ JAM2441.1

Oke, T.R., 1987. Inadvertent modivication of the city atmosphere and the prospect for planned urban climates. Proc. WMO Symp. Meteor, 444: 150-175.
Ozdemir, H., A. Unal, T. Kindap, U.U. Turuncoglu and Z.O. Durmusoglu et al., 2012. Quantification of the urban heat island under a changing climate over Anatolian Peninsula. Theoretical Applied Climatol., 108: 31-38. DOI: $10.1007 / \mathrm{s} 00704-011-0515-8$

Purnomohadi, S., 1995. The role of open green space in the control of air quality in Jakarta. Graduate Program-IPB. Bogor.

Santeramo, F.G., J. Di Pasquale, F. Contò, S. Tudisca and F. Sgroi, 2012. Analyzing risk management in Mediterranean Countries: The Syrian perspective. New Medit, 11: 35-40.

Santoso, I., 1998. Heat island JABOTABEK area. Department of Geophysics and Meteorology, Faculty of Mathematics and Natural Sciences, Bogor Agricultural University.

Sellers, A.H. and P.J. Robinson, 1988. Contemporerly climatology. Hongkong, English Language Book Society/Longman.

Steeneveld, G.J., S. Koopmans, B.G. Heusinkveld and N.E. Theeuwes, 2013. Refreshing the role of open water surfaces on mitigating the maximum urban heat island effect. Landscape Urban Plann., 121: 92-96. DOI: 10.1016/j.landurbplan.2013.09.001

Streutker, D.R., 2003. Satellite-measured growth of the urban heat island of Houston, Texas. J. Remote Sens. Environ., 85: 282-289. DOI: $10.1016 / \mathrm{S} 0034-4257(03) 00007-5$

Svensson, M.K. and I. Eliasson, 2002. Diurnal air temperatures in built-up areas in relation to urban planning. J. Landscape Urban Planning, 61: 37-54. DOI: 10.1016/S0169-2046(02)00076-2

Tan, B.K., R. Adya and H.S. Randeva, 2010. Omentin: A novel link between inflammation, diabesity and cardiovascular disease. Trends Cardiovascular Med., 20: 143-148. DOI: $10.1016 / \mathrm{j} . t \mathrm{~cm} .2010 .12 .002$

Tso, C.P., 1994. The impact of urban development on the thermal environtment of Singapore. Proceedings of the Technical Conference on Tropical Urban Climates, 28 Mar-2 Apr., Dhaka, Bangladesh.

Vaughan, R.A. and A.P. dan Cracnell, 1992. Remote sensing and global climate change. Published in Coorforation with NATO Scientific Affairs Division, New York.

Voogt, J.A., 2002. Urban heat island: Causes and consecuences of global environmental change. John Wiley and Sons, Ltd. Chichester.

Wadrianto, G.K., 2015. Giant Snakes Threaten Farmers Livelihoods.

Wycherley, P.R., 1967. Indices of comport throughout Malaysia. Meteorological Magazine, 96: 73-77.

Zeng, Y., X.F. Qiu, L.H. Gu, Y.J. He and K.F. dan Wang, 2009. The urban heat island in Nanjing. Quaternary Int., 208: 38-43.

DOI: $10.1016 /$ j.quaint.2009.02.018 